\title{
Models of full-time and part-time vocational training for school-leavers: A comparison between Germany and Australia
}

Thomas Deissinger, Erica Smith, and Richard Pickersgill

\begin{abstract}
This article explores some different ways of providing vocational qualifications, specifically for young people who do not go directly to university from school. The examples of Germany and Australia are discussed and show that historical, political, economic and social factors influence the preferred modes of training and their relative perceived status. Advantages and disadvantages are outlined for each mode of provision. Various remedies to address the disadvantages identified for the different modes are explored.
\end{abstract}

\section{Introduction}

In both Germany and Australia only a minority of school-leavers proceed direct to university. In Australia the proportion is a little under 30\%; exact figures are difficult to calculate but unpublished Australian Bureau of Statistics data show a slight decrease annually from a high of 30.2\% in 2001. In Germany, the proportion of school-leavers from general education holding a university entrance qualification (Abitur) in 2003 / 2004 stood at just 23\% which is very low compared to those with a lower or middle school qualification (whose share lies at some 68\%), although it is reported be to be rising (see www.destatis.de). For those not proceeding to university there have been a number of other standard pathways in both countries which may or may not involve training in vocational education and training (VET) qualifications. 
In Germany and Australia alike, similar forces have focused attention on vocational qualifications for young people. These issues include a wish to avoid high youth unemployment, a desire to align young people's skills with the needs of the national economy and local economies, a need continually to extend the coverage of qualifications into emerging industry areas, and a desire to assure the standard and quality of qualifications. In both countries a federal system introduces complexities into the administration of programmes and qualifications.

Those not going to university in Germany have traditionally undertaken apprenticeships through the Dual System which is characterised by the notion of 'skilled recognised qualifications' based on the Vocational Training Act (Greinert, 1994; Deissinger, 1996; Deissinger, 2001a). In the past decades, the German Dual System has been criticised as obsolescent in the face of a rapidly mutating economic and social environment (Greinert, 2004) and has been faced with additional challenges associated with assimilating East Germany and with the general training market situation (Deissinger, 2004b; Deissinger \& Hellwig, 2004). In 2004, the total of 572,980 new training contracts was not high enough to avoid an estimated deficit of training places of some 31,000, leading to a supplydemand ratio (the number of young people looking for places compared with the number of apprentice places available) on the training market which is now at just 95\%, 1.6 percentage points down on 2003 (Federal Ministry of Education and Research, 2005a). Although the two traditional strongholds of training provision, the industrial and the craft sector, (Deissinger, 2001b), did not suffer major declines, the situation for young people remains serious (Ulrich et al., 2005). One of the indicators of this is the rise of young people entering special training programs or opting for vocational courses in full-time VET which represents an ancillary system to the Dual System (Deissinger \& Ruf, 2006; Deissinger, 2005b; Zabeck, 1985).

In Australia, pathways have been a little more diverse and the current situation more favourable. While apprenticeships have been a common form of entry to the labour market, especially for boys, until the late 1980s it was more common for young people to obtain full-time work that did not have a qualification attached to it. From 1987 onwards the option of traineeships became available which led to more qualification-based jobs. Traineeships are in effect a short form of apprenticeships and are generally in industry areas other than the 'traditional trades' (E. Smith, 2003). They were introduced in response to the lack of formal training arrangements in non-craft areas and by the turn of the century had overtaken apprenticeships in numbers of enrolments. Apprenticeships and traineeships alike involve the gaining of a qualification, which may be studied by day or block release, by distance or on-line education, or fully on the job. While most apprenticeships and traineeships involve study at Technical and Further Education colleges (TAFE), the public provider, some qualifications, especially in 'newer' areas such as retail, are provided by private for-profit Registered Training Organisations (RTOs). While apprenticeships and 
traineeships are now open to adults as well, the proportion of young people undertaking them as a percentage of their cohort has remained constant (E. Smith, 2003). Full-time courses are also available, both in the TAFE system, and at private RTOs, and are studied by school-leavers as well as adults. Common areas for such courses in the past have been office administration, beauty therapy and hospitality, where 'traditional' apprenticeships were not available.

In Australia, VET qualifications are now available for study during young people's years of secondary schooling. In Australia, VET in Schools programs are becoming increasingly common, with $44 \%$ of senior secondary schools offering such programs in 2002 (MCEETYA, 2003). As part of these programs, students gain all or part of a national VET qualification. School students also have the option of undertaking school-based apprenticeships and traineeships (almost 17,000 were in training in 20051) which involve being in a part-time apprenticeship or traineeship employment contract and studying at TAFE or a private RTO, which in some cases is the school itself (Smith \& Wilson, 2004). These activities are in addition to a normal senior school curriculum. VET in schools and school-based apprenticeships are outside the scope of this paper but it needs to be borne in mind that as a result of these programs in Australia, young people may now leave school already possessing vocational qualifications or with qualifications part-completed. In Germany, there is no such thing as VET in schools as part of the general education curriculum. There are, however, vocational full-time schools (e.g. vocational colleges), which are part of postcompulsory secondary school education outside the Dual System. Part of their role is to provide vocational qualifications, although these qualifications in most cases are federal state specific profiles or address specific labour markets and are often coupled with the option to gain a higher school qualification (e.g. the Abitur) (Federal Ministry of Education and Research, 2005a). They are not the same qualifications as apprentices gain through the Dual system.

\section{Modes of gaining qualifications}

The various ways in which young people gain VET qualifications can be categorised according to whether their training is full-time, part-time and on-the-job or off-the-job. Three major models can be discerned. Young people gaining qualifications may be:

- $\quad$ Full time at college with no training-contract-related employment;

- $\quad$ Part time at college while working full time in training-contract-related employment (the 'apprenticeship model');

- $\quad$ Full time on the job in training-contract-related employment.

These categories are something of an over-simplification; the boundaries between them are blurred. For example, in Australia full-time college (TAFE or RTO) students will often have additional part-time jobs which may well be 
in a field related to their studies. However the categorisation above refers to employment that is qualification-related. There will also be some cases where the young people are undertaking a part time, rather than full time, on the job apprenticeship or traineeship as their only activity. These are considered to be part of the third category for the purposes of this article. In some cases young people may even be studying one full-time qualification at college while involved in a part-time traineeship, also carrying with it a qualification, in another industry area; such complex pathways are not uncommon in the current youth labour market in Australia (Smith \& Green, 2005). In Germany, the second, 'apprenticeship', type is the most prevalent, whereas the first is less comment and the third model is virtually non-existent. The German training law draws a clear boundary between 'employment' and 'training' contracts (Federal Ministry of Education and Research, 2005b; Deissinger, 1996).

Table 1 indicates some of the potential advantages and disadvantages of each of the three modes of acquiring qualifications. These advantages and disadvantages are derived from the literature (eg V Smith, 2003; Smith, 2002a; Billett, 2001). Many of the points listed are highly contested; for example the learning potential of workplaces is seen by some commentators as high and by others as low. Hence the categorisation is fairly crude, but serves as a startingpoint for discussion and comparisons.

Table 1: Advantages and disadvantages of different modes of acquiring VET qualifications (for young people)

\begin{tabular}{|c|c|c|}
\hline & Advantages & Disadvantages \\
\hline $\begin{array}{l}\text { Full-time at } \\
\text { college }\end{array}$ & $\begin{array}{l}\text { Available to those } \\
\text { without jobs. } \\
\text { Student is able to focus } \\
\text { on learning rather than } \\
\text { production. } \\
\text { Student is more likely } \\
\text { to learn generic and } \\
\text { transferable skills. }\end{array}$ & $\begin{array}{l}\text { Qualification sometimes regarded as low } \\
\text { status. } \\
\text { College may not be able to replicate up } \\
\text { to date workplace environment and } \\
\text { equipment. } \\
\text { Assessment is not undertaken in true } \\
\text { workplace conditions. }\end{array}$ \\
\hline $\begin{array}{l}\text { Part-time at } \\
\text { college/ full time } \\
\text { job } \\
\text { ('apprenticeship } \\
\text { model') }\end{array}$ & $\begin{array}{l}\text { Student gains different } \\
\text { types of learning and } \\
\text { experience in the } \\
\text { different environments. } \\
\text { A balance between } \\
\text { generic skills and } \\
\text { authentic experience. }\end{array}$ & $\begin{array}{l}\text { Lower status compared with the } \\
\text { alternative of higher education. } \\
\text { Not available to those without jobs. } \\
\text { Sometimes perceived to be inadequate } \\
\text { links between work and college. } \\
\text { Employer loses student on his or her } \\
\text { college days. }\end{array}$ \\
\hline
\end{tabular}




\begin{tabular}{|l|l|l|}
\hline $\begin{array}{l}\text { Full time fully on } \\
\text { the job }\end{array}$ & $\begin{array}{l}\text { 'Authentic' learning } \\
\text { environment. } \\
\text { Employer does not lose } \\
\text { worker to part-time } \\
\text { college classes. } \\
\text { Student perceives } \\
\text { training as relevant. }\end{array}$ & $\begin{array}{l}\text { Not available to those without jobs. } \\
\text { Qualification sometimes regarded as low } \\
\text { status. }\end{array}$ \\
& $\begin{array}{l}\text { Employer may not allocate sufficient } \\
\text { time to training. } \\
\text { May be insufficient theory base to } \\
\text { learning. } \\
\text { Qualification can be very narrow, focused } \\
\text { on one situation only. }\end{array}$ \\
\hline
\end{tabular}

\section{Country-specific reasons for preferences for different modes of acquiring VET qualifications}

\section{Australia}

Preference in different countries and among different stakeholder groups for different modes of learning stems partly from historical, social and political reasons. In Australia, apprenticeships have been a feature of the working landscape since the first colonisation by Europeans. The occupational classifications and regulations about apprentice wages and training standards have, historically, been defined through industrial relations agreements (which are known in Australia as 'awards'). Post-trade and para-professional qualifications were also sometimes included. For the last seventy years, federal awards have underpinned the apprenticeship system and have also usually specified some form of off-the-job training. State awards have also contained provisions, and one important feature of the Australian system has been the important role of State governments in building and defending traditional apprenticeship systems (Rushbrook, 2004).

Unlike the United Kingdom, with which Australia is sometimes compared because of similar occupational titles, the Australian apprenticeship system has been closely integrated into industrial relations and intergovernmental frameworks (see Gospel, 1994; Pickersgill, 2001). Although developed within a different institutional and legal structure, outcomes of traditional (i.e. craft and manufacturing) apprenticeships in Australia, based on understandings reached by the social partners through the industrial relations system, had been similar to those achieved in Germany, to the extent that in the late 1980's Australia had a slightly higher proportion of apprentices in training and manufacturing than Germany had (Deveson, 1990). However, unlike arrangements in the countries with Dual systems, Australian employers and their industry associations have not been under obligations to contribute to the VET system through schemes such as training levies (except briefly in the 1980s) or the funding of skill centres. 
Compulsory off-the-job training, specified in awards, has been provided by state funded TAFE colleges, although many large private and public sector organisations and employer groups have also operated their own apprentice training schools. These have significantly declined in importance over the past two decades as employers have sought to externalise training costs.

The growth of traineeships, described earlier, and of a range of providers besides TAFE able to apply for government funding, has been part of a wider process of 'training reform' during the past fifteen years which has also included the advent of competency-based training and the establishment of Training Packages for around 80 industry areas, each containing a range of qualifications (Smith \& Keating, 2003). These qualifications are national and replace a previous system of State-base qualifications which had limited transferability. While apprenticeships and traineeships remain to some extent 'time-served', there are constant challenges to this, particularly from some employer associations, as they would prefer contracts of training to be shortened and allied to competencies achieved only. The various components of training reform have all made it easier to use different modes of delivering qualifications; for example private training providers are more attuned to supporting on-the-job traineeships than is TAFE, the public provider (Smith \& Keating, 2003: 81). However some stakeholders such as trade unions in the craft industries and some of their employer associations are strong advocates for the traditional 'apprenticeship model'; arguments for this model were presented forcefully during a recent government inquiry into skill needs (Senate EWRSBE Committee, 2003).

Arguments have also been put forward for the other modes of delivery. In Australia, it has generally been governments (for equity reasons) and training providers (for market share reasons) who have argued for the availability of the model allowing for full-time delivery at college. Access to such courses is important for those young people who cannot gain work for reasons of geographical location or other disadvantage such as being Aboriginal or migrant. Moreover, in times of economic recession such as the early 1980s and 1990s it was necessary to continue to train young people for trades in preparation for economic recovery, and so a number of 'pre-apprenticeship' full-time courses were introduced (DETYA, 1996). These courses provide the first year of apprentice training, more normally done off the job on day release, in six months full-time, and have generally proved successful in student employment and training outcomes (DETYA, 1996; Dumbrell, 2003). Arguments for the fully on-the-job mode have been strongly put by employer associations, although many individual employers do not necessarily advocate this route, recognising the advantages that can be gained from their young workers learning different ways of doing tasks and mixing with apprentices and trainees from other employers (Smith, 2002a). Traineeships are much more likely than apprenticeships to be fully on the job (Smith \& Keating, 2003: 99). 


\section{Germany}

In Germany, what is now called the Dual System has its roots in the corporatist framework established by legal sanction in the late nineteenth century (Deissinger, 1994; Deissinger, 2004a), which has remained virtually unchanged in its crucial features up to the establishment of the Vocational Training Act (Berufsbildungsgesetz) passed in 1969 and very recently (April 2005) revised. Around the turn from the $19^{\text {th }}$ to the $20^{\text {th }}$ century, compulsory attendance at the part-time vocational school emerged as the second pillar, along with workplace training, underlying formalised vocational training. The dualism of learning sites and legal responsibilities is considered to be the striking feature of the 'German system' of vocational training (Greinert, 1994). Apprenticeships in Germany are characterised by working principles which touch the organisation of the training process as a whole, and thus reach far beyond the dual training arrangement. The Dual System as an apprenticeship system is determined by the notion of vocationalism or the vocational principle (Deissinger, 1998); it is argued that training is not only workplace-led but that the system more broadly works in accordance with skill requirements defined around the workplace (Harney, 1985). Such an objective requires a reliable organisational framework and also the participation of firms. The vocational training law as an input factor and the administrative and organisational contribution of the chambers of industry and commerce are seen as crucial parts of the framework (Ryan, 2001). In addition to the insitutional arrangements, the school law adds mandatory school attendance for virtually everybody who trains in the Dual System. Against this background, in Germany priority has always been given to broad-based knowledge and the acquisition of basic techniques instead of over-specialization or company-specific on the job training (Géhin \& Méhaut, 1995: 65).

The German apprenticeship culture (Harris \& Deissinger, 2003) and the underlying history of vocational training legislation in Germany reflect the notion of the workshop and the idea that apprentices should learn their trade under an experienced master craftsman (Meister). It was during the time of the German Empire (1871-1918) that the small business movement (Mittelstandsbewegung) formed an influential pressure group. The movement was so well represented in Parliament that a series of crucial 'anti-liberal' legal amendments to the trade law were able to be passed (Winkler, 1976). It was above all the Government that held that it made sense to grant economic privileges in return for the Mittelstand's political value to the state. At the heart of these legislative activities, the 1897 Trade Act (Handwerkerschutzgesetz) re-introduced the requirement of formal vocational skills to train apprentices. Although it did not set up the master certificate as a training prerequisite, it revived some important stipulations included in the ancient apprenticeship mode. Chambers and guilds were assigned to organise examinations for journeymen or masters and indentures as well as the model of the three-year training period, at the end of which the apprentice took his examination, 
became the general and virtually mandatory practice in the craft sector.

After the First World War industrial employers began to run vocational schemes which may be seen as the precursors of present training ordinances defined on the basis of the Vocational Training Act. The Chambers of Industry and Commerce emerged as examination bodies for skilled workers, which until then had been confined to the craft guilds and chambers. In due course, industrial employments and apprenticeships had to be systematised and classified. With the passing of the Vocational Training Act in 1969, the divergent developments in the craft and the industrial sector came to an end. Against this background, the traditional notions of the 'whole occupation' and the principle of self-government have their roots clearly in the craft sector whereas industry contributed to the didactical dimension of apprenticeship through the extension and systematisation of technical training schemes within the German Dual System. Thus due to its history and cultural foundations, training in the Dual System now comprises institutional components responsible for skill formation and certification in the context of an occupation-based approach (Ryan, 2001). This firm understanding of process regulation and quality control in apprenticeships comprises, in summary, mandatory part-time courses at the vocational part-time school, compulsory general education and a training law which provides for national uniform training standards in all occupations reflect (Raggatt, 1988).

\section{Addressing the shortcomings of the different models}

The previous section has shown that there are political, social and historical imperatives for the continued existence of each of the three modes of delivery in Australia and the first two in Germany. It is necessary therefore to consider ways in which the inadequacies of each model can be addressed. This section of the paper describes in detail measures which have been taken in one or both of the countries in the study.

\section{Model 1: Full-time at college with no training-contract-related employment}

The focus on the apprenticeship model in Germany implies a huge dependence of the VET system on economic parameters and the labour market situation. If employers choose not to, or cannot, employ young people then it is difficult for the school-leavers to access vocational qualifications. This has been one of the imperatives for the modernisation of the Dual System (Deissinger, 2004b) both on the didactical level (e.g. new training schemes) and through linking up fulltime VET with the apprenticeship system. A similar problem was recognised in Australia, particularly in the periods of high youth unemployment that were associated with economic recessions in the early 1980s and 1990s. In both countries a response was to allow for the study of vocational qualifications fulltime. In Australia, traditional trade courses joined the newer industry areas in full-time qualifications, providing pre-apprenticeship courses that substituted for the college component of the first year of apprenticeships (DEETYA, 1996: 
13). Trade areas included carpentry and joinery and automotive trades. Preapprenticeships are still offered and are attracting increased government attention through programs at both federal and state levels as a means of meeting perceived skills shortages (Dumbrell \& Smith, in progress). This section describes ways in which full-time vocational training is being improved in both countries.

1(a) Adding authenticity to the full time college model through practice firms: Germany

Against the background of the 'training market crisis', Germany's governments, both at the federal and federal state level, have encouraged the rising number of participants in school-based vocational preparation courses as well as full-time students in VET of whom only some $50 \%$ attend courses leading to vocational qualifications that are nationally portable on the labour market (Federal Ministry of Education and Research, 2005a). To improve the status of these courses it is necessary to strengthen the work-related features of VET carried out in vocational full-time schools in order to open up genuine alternative pathways and opportunities for young people outside the Dual System. This has been especially true for the region of Baden-Württemberg through the implementation of practice firms in the 'vocational colleges' (Berufskollegs). The Berufskolleg in the federal state of Baden-Württemberg is an example of such a full-time school type in VET and is chosen to illustrate full-time VET in Germany. Whereas a vocational academy (as a tertiary institution) requires the general university entrance qualification (Deissinger, 2005a), the Berufskolleg is a secondary, but post-compulsory institution, and as such is an alternative to the later years of the grammar school that academic students attend. It is open to students, normally aged between 16 and 18, with a medium-level school leaving qualification. Students emerge from either the two-year vocational full-time school or Berufsfachschule (which takes graduates from the lower secondary schools normally aged 15 or 16 ), the $10^{\text {th }}$ year of lower secondary education (Werkrealschule) or from the two higher streams of the general education system (Gymnasium or Realschule). The place of the Berufskolleg in relation to the general school education and the Dual System is illustrated in Figure 1: 


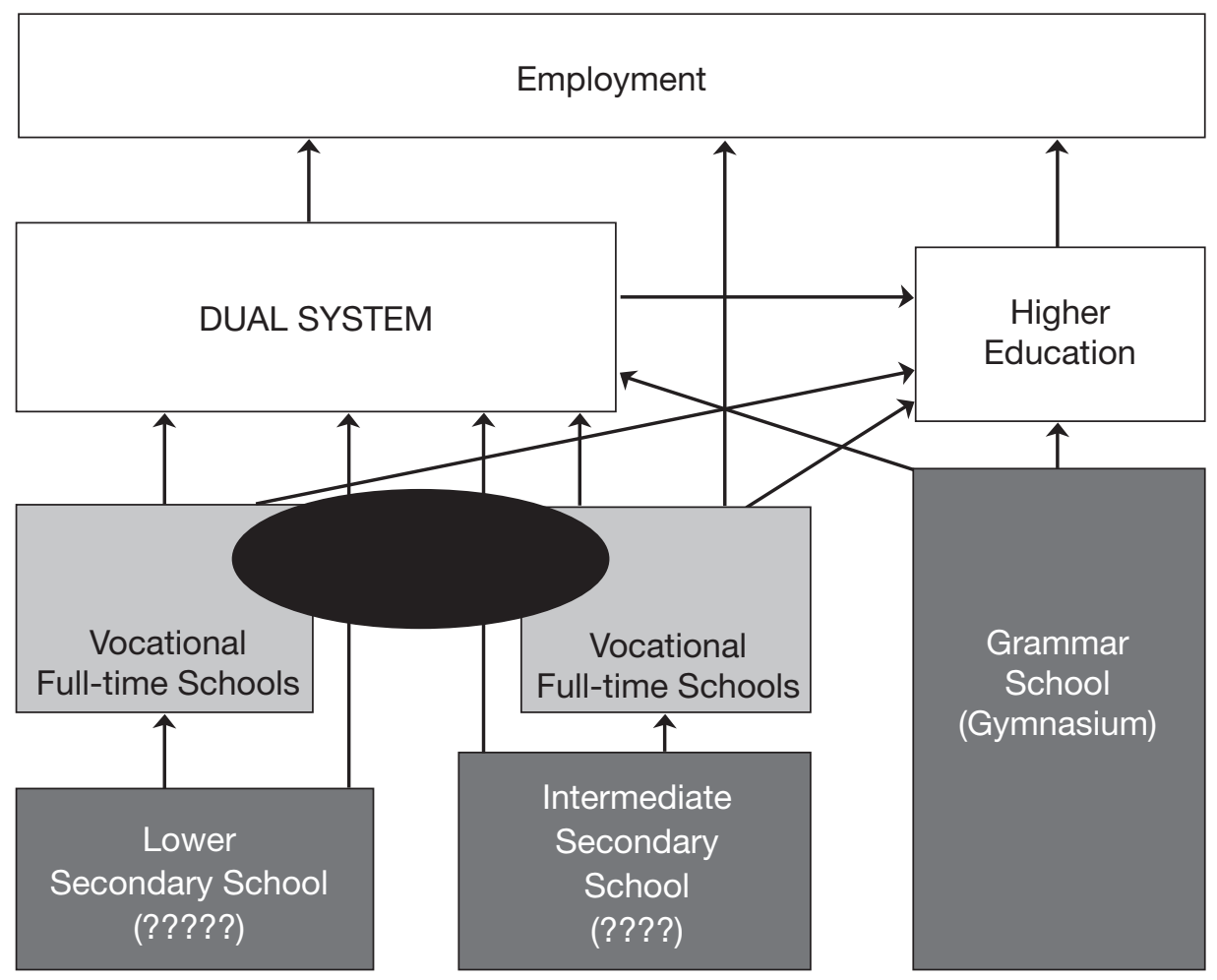

Figure 1: The Vocational College (Berufskolleg) in the German post-compulsory education system

Although the official function of the Berufskolleg is supposed to be a combination of training and educational progression, the findings from a recent research project (Deissinger \& Ruf, 2006) looking at the motivation of students indicate that:

- the occupational qualification (which in the Baden-Württemberg case is the 'commercial assistant' or Wirtschaftsassistent) is generally not valued as useful or attractive - a result which is supported by the fact that most students report their intention to take up an apprenticeship after finishing the course at the Berufskolleg;

- the 'parking function' of the Berufskolleg (ie students attending mainly due to their lack of success in the training market) seems to remain restricted to the first year, while students in their second year have a clear understanding of their goals and motivations including taking up an apprenticeship after the second year of the course;

- the Berufskolleg takes the role of a 'bridge' between school education and the Dual System and therefore cannot be regarded as a substitute or alternative in relation to the apprenticeship system. 
One of the pedagogical tools supposed to make vocational schools practical and, in the case of the Berufskolleg, to increase the marketability of the commercial assistant qualification is the ongoing implementation of practice firms. In the German educational debate, practice firms have returned to the agenda since the 1980s, although it should be noted that theory and reality of practice firms often differ. In Baden-Württemberg, practice firms are seen as learning arrangements which are supposed to give full-time VET a new face and increase its attractiveness both among students and employers. All in all, some 90 practice firms are currently in operation in commercial school centres in Baden-Württemberg.

With the slackening training market and the ongoing discussion referring to both alternative pathways and their accreditation with respect to occupational qualifications normally obtained through an apprenticeship, vocational full-time schools could become more occupation-orientated which however requires that their relevance both for skilled employment and for a subsequent apprenticeship course need to be improved (Feller, 2002). Although the revised Vocational Training Act (2005) provides for a wider scope of accreditation modes in the responsibility of the federal states (Lorenz, Ebert \& Krüger, 2005; Federal Ministry of Education and Research, 2005b) the question remains whether, from an educational and social perspective, practice firms promote the employability of young people by developing skills in realistic learning environments which are able to simulate problems and work activities normally typical for workplaces in companies.

The basic features of a practice firm may be characterised as follows (Reetz, 1986):

- A practice firm is a fictitious company within a vocational school that works in most respects like a normal company;

- All commercial departments are represented within a practice firm;

- However there is no real exchange of goods and money;

- Practice firms co-operate with other practice firms within a national and international network;

- A real company normally provides support, money and the product names for the training firm;

- The normal number of lessons per week lies between five and seven (in Baden-Württemberg in the Berufskolleg).

Pedagogical expectations of the practice firm concept refer to the presumed benefits of an innovative learning arrangement which puts both the teacher and the student into different roles by requiring a new understanding of the relationship between teaching and learning as opposed to normal classroom settings of lessons in business administration or economics. It is assumed that 
practice firms help learners to develop a more substantial understanding of business processes and a 'feeling' for realistic workplace conditions, although the practice firm remains primarily a pedagogical institution. Practice firms are seen as learning arrangements which help to overcome the 'dualism of thinking and acting' (Tramm, 1994) and therefore follow those criteria underlying the concept of 'activity orientation' (Handlungsorientierung) now seen as the dominant and most innovative pedagogical concept within the current VET debate (Czycholl, 2001).

However, while there seems to be a clear pedagogical value in the perception of students and teachers when learning and teaching in the practice firm setting, the impact on external stakeholders appears modest. Chambers and companies still believe that socialisation during an apprenticeship producing real working experiences cannot be equalled by a full-time model of VET. In the project mentioned above (Deissinger \& Ruf, 2006), only 60\% of companies reported that they supported partial accreditation of prior learning into a follow-up apprenticeship, and, with the exception of craft enterprises, firms were even more negative, when it came to accepting the commercial assistant qualification for employment. Against this background, it is very likely that only 'sandwich models' - dualising learning by combining internships (the usual term for work placements in Germany) or reduced periods of apprenticeship training with full-time vocational courses in a Berufskolleg or a similar institution - may in future function as partial or full substitutes for an apprenticeship. This, of course, puts strain on the practice firm concept and its political and pedagogical legitimation.

1 (b) Adding authenticity to the full time college model through work placements: Australia

Although practice firms are also utilised in Australia, another method of adding authenticity to full time study at technical college is also common: this is the inclusion of work placements in courses. In Australia this is a favoured mode, and is actively encouraged because Training Package qualifications often mandate that certain tasks must be assessed in the workplace. Sometimes simulated workplaces are acceptable in Training Package regimes, but not always. Units of competency in the qualifications make such requirements quite clear.

Work placements carry a number of risks and benefits, whether they are part of school, university or technical college courses. These have been summarised as follows in Smith \& Keating (2003: 206):

Benefits

- Students get a 'real' or 'authentic' experience of work;

- Students see how individual skills fit into the context of a job and a workplace;

- Generic skills can be developed in meaningful ways; 
- Students may get employment directly or indirectly through their placement (if they are not already employed); and

- VET teachers build up close links with industry, which improves the quality of their teaching with time for discussion, students can learn from their fellow students' experiences.

Risks

- Students will not all get comparable experiences;

- Standards of supervision of students may vary;

- Standards of assessment may vary;

- It can be difficult for college staff to visit the workplaces, especially in rural areas where placements may have to be distant; and

- Organising and monitoring the work placement is time-consuming and such tasks can be difficult to fit around a teacher's classroom duties.

The Australian VET system's quality assurance process (the Australian Quality Training Framework) requires that training providers remain ultimately responsible for workplace assessment that leads to qualifications which the providers award (Smith \& Keating, 2003: 66), but workplace supervisors and assessors are often involved as minor partners in gathering evidence for assessment of students that are on placements and, of course, are responsible for providing on the job training. Although the tasks to be assessed are embedded within units of competency which form part of Training Package qualifications, training providers may add an additional 'module' onto courses which consists of workplace practice, rather than delivering small parts of the each of the different units in the workplace. In this work placement module, the tasks which need to be assessed in the workplace are gathered together.

The advent of Training Packages with the requirement, described above, for workplace assessment created some turmoil in the VET system in the late 1990s (Smith, 2002b), not least caused by panic at the thought of needing to find large numbers of employers willing to take students on placement. A well-publicised successful example in Australia was Douglas Mawson TAFE Institute in South Australia. Staff faced the challenges posed by new Information Technology (IT) courses by examining a number of models for workplace assessment and determining that a work placement was normally required, unless a student was unable to find a placement, in which case they were allowed to work in the college's practice firm (Ruiz, Earl, Ruiz \& van den Broeke, 2001). An evaluation of the first year of offering showed that of 124 students in IT courses in 2000, 67 undertook placements, 37 were excused placement because of recognition of current competency or because they failed the course before they reached the placement module, and 20 students went into the practice firm instead. Of the 67 students for whom work placements were successfully obtained, 57 (85.1\%) passed the module (Ruiz et al, 2001:6). 
Model 2: The apprenticeship model: Addressing the factors of loss of status and reliance on employment

In both Australia and Germany, governments have implemented a range a measures to boost the 'dual' system of apprenticeships. The 'dual' system relies upon employers offering jobs and also upon young people seeing apprenticeships as attractive career options as opposed to other possibilities, and in both countries measures have attempted to address both of these issues.

In Australia, a combination of incentives has been highly successful in boosting apprenticeship and traineeship numbers to over 393,800 in 2004 (NCVER, 2005) (from a total population of 21 million). Of this total, $41 \%$ were aged under 19 (NCVER, 2005); in the early 1990s contracts of training were made available to people of all ages. Incentives include Australian Commonwealth (national) incentives to employ apprentices and trainees, payable partly at the commencement and partly at the end of the contract, and user choice funding which is provided by States and Territories for the off the job training (which may be provided on the job under certain circumstances) given to apprentices and trainees. In addition, intermediary agencies - Group Training Organisations and New Apprenticeship Centres - have been set up to market apprenticeships and traineeships to employers, and to help young people find and succeed in apprenticeships and traineeships. These developments have not been without controversy. Some commentators believe that traineeships are a debased type of qualification (eg Hampson, 2002). There has been some evidence of inappropriate accessing of government funding in traineeships, which has been well-documented in reviews of traineeships in several States (eg Schofield, 1999). Moreover there is opposition (from some employers and some unions alike) both to the use of the terms apprenticeship and traineeship for adult workers, and to the administration of funding under the same systems for both adults and young people (Senate EWRSBE committee, 2003). Other, non-institutional, strategies over the past twenty years have included heavy marketing of apprenticeships and traineeships by the Federal Government's Department of Education Science and Training and the Australian National Training Authority and the funding of a range of labour market programmes to assist unemployed or at-risk young people into work (DEETYA, 1996); such programmes increasingly involve formal qualifications. The growth of private providers with access to government funding, as discussed above, has facilitated the availability of off-the-job training for a broader range of apprenticeships and traineeships.

In Germany, besides the measures already described at the federal state level, initiatives that have assisted school-leavers' access to VET qualifications have included several strategies:

- State-subsidised training within and outside companies in order to stabilise the particularly critical situation on the training market in the new federal states; 
- Vocational training campaign by the Federal Government - together with workers, employers, federal state governments and others responsible for VET - focussing on the creation of training places;

- Identification of tools and organisation of marketing campaigns which in regions with a considerable shortage of training places could help to introduce non-training companies to VET under the Dual System;

- Implementation of a training levy for non-training enterprises to support companies that train (cancelled for the time being);

- Stronger support of sectoral, regional and in-company training place initiatives and collaborative vocational training ventures as well as training schemes organised by external providers in close co-operation with local enterprises with a view to developing sustainable VET structures, also in problem regions in the western part of the country;

- New stipulations in the revised Vocational Training Act (2005) to integrate vocational preparation programmes into the formal VET system more reliably;

- More company-oriented design of the training place programme for eastern Germany launched by the federal and federal state governments.

To address the issue of insufficient apprentice places, the Federal Government has also introduced the concept of training place developers (Ausbildungsplatzen twickler) in order to secure the long-term provision of training places and detach it from the contingencies on the labour market. These have some similarities to Australian intermediary agencies such as New Apprenticeship Centres and Group Training Organisations. The role of the Ausbildungsplatzenwickl er includes helping companies to cope with administrative work linked to an apprenticeship, establishing co-operation with vocational schools and helping to set up company-specific training plans. With another programme called STARegio, regional joint training provision is to be promoted which means that companies pool together in order to enable young people to achieve all the competences within a given occupational training scheme (for all measures see Federal Ministry of Education and Research, 2005a).

\section{Model 3: Full time on the job training (Australia only)}

As mentioned above, some controversy surrounds fully on the job apprenticeships and traineeships in Australia. In the mid-1990s a number of agencies were funded by national and state governments to promote the growth of apprenticeships and traineeships and subsidies were heavily marketed to employers (for recruiting apprentices and trainees and for completion of their contracts of training) and to training providers (for providing training and assessment). It was shown very clearly by Schofield (1999) and others that on the job traineeships were more open to abuse of such funding than traineeships 
which included off the job training. This is not to imply that all on-the-job traineeships are worthless. Most States and Territories took heed of the research findings, and withdrew funding from some on the job traineeships. In addition, changes were made in some States to the rules about the supervision by training providers of their on the job trainees, including provision for specified numbers of visits and the delivery of 'real training' for a certain number of hours. Anecdotal evidence from TAFE teachers indicates that it is often quite difficult for visiting teachers to talk to employers about training and to ascertain that the trainees are really receiving training while they are working. Nevertheless, some employers take their duties very seriously; for example one large fast food chain uses the training funding to fund extra training positions to give more intensive training to its young trainees (Smith \& Comyn, 2003). It is likely that on the job apprenticeships and traineeships will continue to improve in quality. This will occur through a combination of continued policy attention to the way in which subsidies can be managed to provide for good training outcomes, audits of training providers under the Australian Quality Training Framework, and, importantly, professional development for training provider staff who visit these young people and their employers in the workplace.

\section{Conclusion}

A comparison of German and Australian provision of post-compulsory vocational qualifications available to school-leavers people reveals both similarities and differences. The underpinnings of the vocational training systems for young people in the two countries can be summed up as follows. In both countries there is an apprentice tradition that reaches back for several centuries; in both countries there has to be an employment basis for apprenticeship. Both countries have legislative frameworks that have built industrial relations provisions around the apprentice system, although these frameworks are of differing strength, being much stronger in Germany currently, although historically they were just as strong in Australia. There is recognition of the importance of both off the job and on the job training in both countries, but in Germany this is more deeply rooted. The role of individual employers in the system, beyond the basic role of employing apprentices, is stronger in Germany (for example in carrying out examinations), while in both countries employer associations have influenced policy developments over a long period of time. In both countries the intervention of governments in apprenticeship arrangements at both Federal and State ('federal states' in Germany)level is seen as legitimate and desirable.

These underpinnings have affected the development of the different models described above. Both countries are facing some common problems with the traditional apprenticeship model (Model 2), which include the difficulty of attracting young people into some occupations and the reluctance of some employers to make the necessary investment in the system by employing young people in apprenticeships. In order to increase the labour market chances of 
young people, and to address skill needs, both governments have instituted a number of initiatives at both federal and state level to improve enrolments. However these are enacted differently according to differences in culture and tradition. In both countries, one way of addressing lack of apprentice places is to offer vocational courses full-time (Model 1) but this alternative lacks legitimacy in the eyes of some stakeholders and therefore various methods of introducing authentic workplace elements have been tried in both countries. Only in Australia is the fully on the job method of gaining vocational qualifications (Model 3) a possibility. The deeply entrenched nature of the 'dual' system in Germany is likely to preclude this as a possibility in that country.

Probably the most important finding of this review of practices in the two countries is the very active attention that is paid to the issue in both countries; both at governmental and training provider level, initiatives are constantly being developed to widen young people's participation in vocational qualifications through offering different modes of delivery.

Professor Dr. Thomas Dessinger is Professor of Business Education at the University of Konstanz, Germany.

Dr Erica Smith is Associate professor of Vocational Education and Training at Charles Sturt University, Australia

Richard Pickersgill is Lecturer in Vocational Education and Training at Charles Sturt University, Australia.

\section{References}

Billett, S 2001, Learning in the workplace: Strategies for effective practice, Allen \& Unwin, Sydney.

Czycholl, R 2001, Handlungsorientierung und Kompetenzentwicklung in der beruflichen Bildung. In: Bonz, B. (Ed.): Didaktik der beruflichen Bildung, Schneider, Baltmannsweiler, pp. S. 170-186.

Deissinger, $\mathrm{T}$ 1994, The evolution of the modern vocational training systems in England and Germany: A comparative view. Compare. A Journal of Comparative Education, vol. 24, pp.17-36.

Deissinger, T 1996, Germany's Vocational Training Act: Its function as an instrument of quality control within a tradition-based vocational training system, Oxford Review of Education, vol. 22, pp. 317-336.

Deissinger, T 1998, Beruflichkeit als „organisierendes Prinzip” der deutschen Berufsausbildung, Eusl, Markt Schwaben.

Deissinger, $\mathrm{T} 2001^{\circ}$, Entwicklung didaktisch-curricularer Vorgaben für die Berufsbildung in Deutschland. In: Bonz, B. (Ed.): Didaktik der beruflichen 
Bildung, Schneider, Baltmannsweiler, pp. 71-87.

Deissinger, $\mathrm{T}$ 2001b, Vocational training in small firms in Germany: The contribution of the craft sector, Education and Training, vol. 43, no. 8/9, pp. 426-436.

Deissinger, T 2004a, Apprenticeship systems in England and Germany: decline and survival. In Greinert, W.-D. \& Hanf, G. (Eds.): Towards a history of vocational education and training (VET) in Europe in a comparative perspective, Proceedings of the First International Conference, October 2002, Florence, Vol. I., Office for Official Publications of the European Communities, Luxembourg, pp. 28-45.

Deissinger, T 2004b, Germany's system of vocational education and training: challenges and modernisation issues, International Journal of Training Research, vol. 2, no. 1, pp. 76-99.

Deissinger, T 2005a, Links between vocational education and training (VET) and higher education: The case of Germany. In: Gallacher, J. \& Osborne, M. (Eds.): A Contested Landscape. International perspectives on diversity in mass higher education. National Institute of Adult Continuing Education, Leicester, pp. 92-116.

Deissinger, T 2005b, Zur Frage der Verwertbarkeit schulischer Berufsbildung am Beispiel der baden-württembergischen Berufskollegs: Welchen Beitrag leisten didaktische Innovationen? In: Jacob, M. \& Kupka, P. (Eds.): Perspektiven des Berufskonzepts - Die Bedeutung des Berufs für Ausbildung und Arbeitsmarkt. Nürnberg: Institut für Arbeitsmarkt- und Berufsforschung der Bundesagentur für Arbeit, pp. 143-158.

Deissinger, T \& Hellwig, S 2004, Initiatives and strategies to secure training opportunities in the German vocational education and training system, Journal of Adult and Continuing Education, vol. 10, no.2, pp. 160-174.

Deissinger, T \& Ruf, M 2006, Übungsfirmen am Kaufmännischen Berufskolleg in Baden- Württemberg. Praxisorientierte vollzeitschulische Berufsausbildung zwischen Anspruch und Wirklichkeit. Eusl, Paderborn.

Department of Employment, Education, Training \& Youth Affairs (DEETYA), Evaluation \& Monitoring Branch 1996, Training in a recession: An evaluation of the effectiveness of providing additional pre-vocational training places 1991 and 1992, DETYA, Canberra.

Deveson, I (Training Costs Review Committee chairperson) 1990, Training costs of award restructuring. Report of the Training Costs Review Committee, AGPS, Canberra. 
Dumbrell, T 2003, Pathways to Apprenticeship. National Centre for Vocational Education Research, Adelaide.

Dumbrell T \& Smith, E (in progress), Pre-apprenticeships: Policy options in the key trades, reserch project funded by National Centre for Vocational Education Research.

Federal Ministry of Education and Research 2005a, Berufsbildungsbericht 2005. BMBF, Bonn.

Federal Ministry of Education and Research 2005b, Die Reform der beruflichen Bildung - Berufsbildungsgesetz 2005. BMBF, Bonn.

Feller, G 2002, Leistungen und Defizite der Berufsfachschule als Bildungsgang mit Berufsabschluss. In: Wingens, M. \& Sackmann, R. (Eds.): Bildung und Beruf.Ausbildung und berufsstruktureller Wandel in der Wissensgesellschaft, Juventa, Weinheim, pp. 139-157.

Géhin, J P \& Méhaut, P 1995, The German Dual System: A model for Europe? Industrielle Beziehungen, vol. 2, no. 1, pp. 64-81.

Gospel, H F 1994, The survival of apprenticeship training: A British, American, Australian comparison, British Journal of Industrial Relations, vol. 32, pp. 505-522.

Greinert, W D 1994, The German system of vocational training: History, organization, prospects, Nomos, Baden-Baden.

Greinert, W D 2004, Das „deutsche System” der Berufsausbildung am Ende seiner Entwicklung? Zeitschrift für Berufs- und Wirtschaftspädagogik, vol. 100., no. 1, pp. 106-115.

Hampson, I 2002, Training reform: Back to square one? The Economic and Labour Relations Review, vol. 13, no. 1, pp. 149-174.

Harney, K 1985, Der Beruf als Umwelt des Betriebs. Vergleichende, historische und systematische Aspekte einer Differenz. In: Verbände der Lehrer an beruflichen Schulen in Nordrhein-Westfalen (Eds.): Die Relevanz neuer Technologien für die Berufsausbildung. Krefeld, pp. 118-130.

Harris, R \& Deissinger, T 2003, Learning cultures for apprenticeships: A comparison of Germany and Australia. In: Searle, J., Yashin-Shaw, I. \& Roebuck, D. (Eds.): Enriching Learning Cultures. Proceedings of the 11th Annual International Conference on Post-compulsory Education and Training, Volume Two, Australian Academic Press, Brisbane, pp. 23-33. 
Lorenz, K, Ebert F \& Krüger, M 2005, Das neue Berufsbildungsgesetz - Chancen und Grenzen für die berufsbildenden Schulen in Deutschland. Wirtschaft und Erziehung, vol. 57, no. 5, pp. 167-174.

Ministerial Council for Employment Education Training \& Youth Affairs (MCEETYA) 2003, National data on participation in VET in Schools: Programs and school-based new apprenticeships for the 2002 school year, Report of the MCEETYA Transitions to Work taskforce, MCEETYA secretariat, Adelaide.

National Centre for Vocational Education Research (NCVER) 2005, Apprentices and trainees - September quarter 2004, Summary, NCVER, Adelaide.

Pickersgill, R 2001, Skill formation in Australia beyond 2000. International Journal of Employment Studies, vol. 9, No 1, April, pp. 121-139.

Raggatt, P 1988, Quality control in the Dual System of West Germany, Oxford Review of Education, vol. 14, pp. 163-186.

Reetz, L 1986, Die Übungsfirma in der kaufmännischen Berufsausbildung. Didaktische Möglichkeiten und Grenzen einer Organisationsform wirtschaftsberuflichen Lernens. In: Kutt, K. \& Selka, R. (Eds.): Simulation und Realität der kaufmännischen Berufsausbildung, Berlin, pp. 219-240.

Ruiz, S, Earl, R, Ruiz, J \& van den Broeke, P 2001, The IT Training Package and the workplace training context - HOW? Paper presented to the 4th National Conference of the Australian VET Research Association: Research to Reality: Putting VET Research to Work, Adelaide, 28-30 March 2001.

Rushbrook, P 2004, Tradition and the construction of technical and further education in Victoria, Australia, 1839-1992, Paper presented to the 13th Biennial Conference of the Canadian History of Education Association: Interdisciplinarity in the Practice and Theory of Educational Histories, Calgary, Alberta, 21-14 October 2004.

Ryan, P 2001, Apprenticeship in Britain - Tradition and Innovation. In: Deissinger, T. (Ed.): Berufliche Bildung zwischen nationaler Tradition und globaler Entwicklung. Nomos, Baden-Baden, pp. 133-157.

Schofield, K 1999, Independent investigation into the quality of training in Queensland's traineeship system, Department of Employment, Training and Industrial Relations, Vocational Education, Training and Employment Commission, Brisbane.

Senate Employment, Workplace Relations, Small Business \& Education Committee 2003, Bridging the skills divide, Senate Printing Unit, Canberra. 
Smith, E 2002a, Theory and practice: The contribution of off-the-job training to the development of apprentices and trainees, Journal of Vocational Education and Training, vol. 5, no. 3, pp. 431-453.

Smith, E 2002b, Training Packages: Debates around a new curriculum system, Issues in Educational Research, vol. 12, no. 1, pp. 64-84.

Smith, E 2003, The scope for state Intervention in young people's learning and training. Journal of Education and Work, vol. 16, no. 4, pp. 385-406.

Smith, E \& Comyn, P 2003, The development of employability skills in novice workers through employment, NCVER, Adelaide.

Smith, E \& Green, A 2005, How workplace experiences while at school affect career pathways, NCVER, Adelaide.

Smith, E \& Keating, J 2003, From training reform to Training Packages, Social Science Press, Tuggerah Lakes, NSW.

Smith, E \& Wilson, L 2004, School based apprenticeships and traineeships in Australia, Education and Training, vol. 46, no. 2, pp. 64-74.

Smith, V 2003, Raising retention and achievement in work-based learning, Education and Training, vol. 45, no. 5, pp. 273-279.

Tramm, T, 1994, Die Überwindung von Dualismus von Denken und Handeln als Leitidee einer handlungsorientierten Didaktik. Wirtschaft und Erziehung, vol. 46 , pp. 39-48.

Ulrich, J G et al, 2005, Trotz Zuwachs bei den Ausbildungsverträgen noch keine Entlastung auf dem Ausbildungsstellenmarkt. Berufsbildung in Wissenschaft und Praxis, vol. 34, no. 1, pp. 49-50.

Winkler, H A 1976, From social protectionism to National Socialism: The German small-business movement in comparative perspective. Journal of Modern History, vol. 48, pp.1-18.

Zabeck, J 1985, Berufliche Bildung, in: Staatslexikon Recht - Wirtschaft Gesellschaft, Vol. 1, Freiburg: Herder, pp. 669-683.

\section{(Footnotes)}

1 School-based apprenticeship numbers obtained from National Centre for Vocational Education Research, unpublished data. 